\title{
Analisis LKM Posdaya Kenanga Terhadap Tingkat Pendapatan Pelaku Usaha Mikro di Kelurahan Situ Gede
}

\section{Analyzing The Implementation of LKM Posdaya Kenanga to Micro Entrepreneur Income Level in Situ Gede Village}

\author{
Nur Cholilah Junita Dalimunthe ${ }^{1}$, Murdianto ${ }^{1}$ \\ ${ }^{1}$ Departemen Sains dan Komunikasi Pengembangan masyarakat, \\ Fakultas Ekologi Manusia, Institut Pertanian Bogor, Bogor
}

\begin{abstract}
LKM is a financial institution that serves to distribute micro-credit to the poor or low-income community. The granted micro-credit is expected to help the community, especially micro entrepreneurs to be able to expand their business. Business development is a strategic step to increase micro entrepreneur revenue. However, LKM should consider about the level of target accuracy, resource provivion, and movement development. This research aimed to analyze the implementation of LKM Posdaya Kenanga to micro entrepreneur income level in Situ Gede Village. The research methods were The Rank Spearman Test and Cross Tabulation which were used to determine the existence of relationship between the implementation of LKM to micro entrepreneur income level. The results showed that the implementation of LKM Posdaya Kenanga did not have positive and significant relationship to micro entrepreneur level because the amount of micro entrepreneur income was generally low.
\end{abstract}

Keywords: micro credit, micro entrepreneurs, micro enterprises development

Abstrak

LKM adalah suatu lembaga keuangan yang berfungsi untuk menyalurkan kredit mikro kepada masyarakat miskin atau berpendapatan rendah. Kredit mikro yang diberikan diharapkan dapat membantu masyarakat, terutama pelaku usaha mikro untuk dapat mengembangkan usahanya. Pengembangan usaha adalah salah satu langkah strategis untuk meningkatkan pendapatan pelaku usaha mikro.Namun, LKM harus mempertimbangkan mengenai tingkat ketepatan sasaran, tingkat pemberian sumber daya, dan tingkat pengembangan gerakan. Tujuan dari penelitian ini adalah untuk menganalisis implementasi LKM Posdaya Kenanga terhadap tingkat pendapatan pelaku usaha miro di Kelurahan Situ Gede. Penelitian ini menggunakan metode Rank Spearman dan tabulasi silang yang digunakan untuk menentukan hubungan antara implementasi LKM terhadap tingkat pendapatan pelaku usaha mikro. Hasil penelitian menunjukkan bahwa implementasi LKM tidak memiliki hubungan positif dan nyata terhadap tingkat pendapatan pelaku usaha mikro karena tingkat pendapatan pelaku usaha mikro secara keseluruhan rendah.

Kata kunci: kredit mikro, pelaku usaha mikro, pengembangan usaha mikro, implementasi LKM

\section{Pendahuluan}

Indonesia memiliki jumlah penduduk sebesar 237.641 ribu jiwa menurut Hasil Sensus Penduduk tahun 2010 (BPS, 2012). Pekerjaan penduduk di Indonesia sebagian besar masih didominasi oleh Usaha Mikro, Kecil, dan Menengah (UMKM). Perkembangan data UMKM tahun 2009-2010 menunjukkan usaha mikro memiliki jumlah sebanyak 52.176.795 pada tahun 2009, selanjutnya pada tahun 2010 meningkat menjadi 53.207.500. Ini menandakan peningkatan jumlah sebesar 1.030 .705 atau 1,98\%. Triyanto et al. (2012) menyebutkan jenis pekerjaan ini banyak digeluti karena memiliki ciriciri pengelolaan yang bersifat keluarga, penggunaan teknologi sederhana, modal yang kecil dengan tenaga kerja 1-20 orang, dan belum menerapkan manajemen yang modern, namun UMKM mempunyai peran yang strategis dalam perekonomian nasional, terutama dalam penyerapan tenaga perekonomian di daerah.

Perkembangan UMKM ini juga tidak lepas dengan diiringi banyaknya kendala yang dihadapi, seperti kurangnya modal dan jaringan pemasaran. Modal yang tidak mencukupi dapat menjadi masalah yang menimbulkan siklus rantai kemiskinan yang sulit untuk diputus. Menurut Ashari (2006) lemahnya permodalan pelaku ekonomi di Indonesia, terutama di pedesaan telah disadari oleh pemerintah yang akhirnya meluncurkan beberapa kredit program. Kredit program ini ditujukan kepada petani dan pelaku usaha kecil 
dan mikro sejak Repelita I. Namun, kredit program yang diselenggarakan oleh pemerintah dipandang belum berhasil. Oleh karena itu, dibentuklah Lembaga Keuangan Mikro (LKM) untuk membantu menyalurkan kredit kepada masyarakat.Keterbatasan usaha mikro dan kecil dalam mengakses lembaga perbankan formal merupakan potensi pasar yang sangat besar yang bisa menjadi ladang garapan LKM. Pengembangan LKM diyakini merupakan faktor penting dalam upaya penanggulangan kemiskinan serta pembangunan ekonomi pedesaan. Selain itu, pengembangan keuangan mikro merupakan bagian usaha untuk mengembangkan sistem keuangan, baik lokal maupun nasional yang sesuai dengan kondisi rakyat (people based financial system). Ini didukung dengan temuan Abdullah (2006) dalam Nuswantara (2012) yang menyebutkan kondisi lainnya juga digambarkan bahwa pasar usaha mikro dan kecil yang digarap oleh perbankan baru sekitar 30\% saja secara nasional, dan $70 \%$ sisanya, belum tergarap oleh perbankan nasional.

LKM diharapkan dapat membantu UMKM dalam mengatasi masalah modal, sehingga mampu menjalankan dan mengembangkan usahanya agar lebih sustainable. Namun, LKM juga harus dapat menyesuaikan persyaratan dan proses yang ditawarkan sesuai dengan kemampuan UMKM. Pada dasarnya, UMKM membutuhkan pembiayaan yang sesuai dengan sifat dan skala usahanya. Lebih lanjut, LKM harus dapat memberikan pelayanan keuangan dengan bunga ringan, persyaratan yang mudah, dan proses pencairan dana yang cepat, yang mana masih belum bisa dipenuhi oleh lembaga perbankan formal. Hasil penelitian Kurniawan (2008) menunjukkan pengaruh menjadi anggota Koperasi Baitul Ikhtiar (BAIK) terhadap peningkatan pendapatan adalah positif 0,0397\% lebih tinggi, dibandingkan yang bukan anggota pada studi kasus industri sepatu di Desa Sukaluyu, Kecamatan Tamansari, Kabupaten Bogor.

Pos Pemberdayaan Keluarga (Posdaya) adalah suatu forum yang dibentuk oleh Yayasan Damandiri guna meningkatkan taraf hidup masyarakat. Fungsi Posdaya bukan hanya mampu menyemarakkan kembali budaya gotong-royong dan peduli kepada sesama, tetapi juga mengangkat berbagai potensi yang dimiliki baik sumber daya alam maupun warganya guna meningkatkan kemandirian dan kesejahteraan. Merambahnya Posdaya yang dipimpin oleh Ketua Yayasan Damandiri, Prof Dr Haryono Suyono ternyata mampu menggerakkan masyarakat
Kelurahan Situ Gede, Kecamatan Bogor Barat, Kota Bogor menuju kemandirian dengan memanfaatkan sumber daya serta potensi lokal yang ada.

Kelurahan Situ Gede terletak $5 \mathrm{~km}$ dari Kota Bogor. Jumlah penduduk sebesar 7.941 jiwa yang terbagi ke dalam 2.228 Kepala Keluarga (KK), sebagian besar jenis pekerjaan penduduknya adalah Pedagang dan Petani. Jenis pekerjaan yang relatif sama dan dilakukan oleh banyak orang dapat mengurangi tingkat pendapatan, disebabkan oleh tingkat persaingan yang tinggi. Namun, adanya pengembangan atau inovasi usaha dapat membuka peluang untuk meningkatkan pendapatan. Pengembangan usaha untuk meningkatkan pendapatan, tidak lepas dari dibutuhkannya modal untuk membeli bahan baku, alat produksi, dan alat distribusi.

Posdaya Kenanga merupakan Posdaya yang berada di Kelurahan Situ Gede, Kecamatan Bogor Barat, Kota Bogor. Posdaya ini merupakan binaan Pusat Pengembangan Sumberdaya Manusia (P2SDM) dan Lembaga Penelitian dan Pengabdian kepada Masyarakat (LPPM) Institut Pertanian Bogor (IPB) serta para mahasiswanya. Posdaya ini telah berdiri selama satu setengah tahun, tepatnya pada 22 Mei 2010. Pelayanan yang diberikan meliputi bidang kesehatan, pendidikan, ekonomi, dan pengembangan lingkungan. Di bidang ekonomi terdapat suatu Lembaga Keuangan Mikro (LKM) yang berfungsi untuk menyalurkan kredit mikro (pinjaman) kepada pelaku usaha mikro. LKM ini mendapatkan dana pinjaman dari Yayasan Damandiri melalui Koperasi Tabur Puja agar dapat disalurkan kepada masyarakat yang membutuhkan modal guna mengembangkan usahanya. Sebagian besar masyarakat yang bertempat tinggal di sekitar Kelurahan Situ Gede ikut serta mengisi surat permohonan guna memperoleh kredit mikro. Ini dapat dilihat dari jumlah peminjam yang ada, yakni sebanyak 73 orang. Jumlah peminjam ini belum termasuk dari jumlah keseluruhan masyarakat yang telah mengajukan permohonan pinjaman, tetapi belum mendapatkan kesempatan untuk memperoleh pinjaman disebabkan terbatasnya dana pinjaman.

Keberadaan LKM Posdaya Kenanga membuka akses masyarakatterhadap penyediaanmodal. Tersedianya akses terhadap modal diharapkan dapat membantu masyarakat untuk mengembangkan usahanya guna meningkatkan pendapatan. Data yang ada menunjukkan bahwa jenis usaha di Indonesia masih didominasi oleh usaha mikro. Atas dasar pemikiran di atas, diperlukan 
penelitian mengenai Analisis Implementasi LKM Posdaya Kenanga terhadap Tingkat Pendapatan Pelaku Usaha Mikro di Kelurahan Situ Gede.

Tujuan dari penelitian ini yaitu (a) menganalisis implementasi LKM Posdaya Kenanga terhadap pelaku usahamikroyangmemperolehpinjamandalamkegiatan pemberdayaan, (b) menganalisis pengembangan usaha mikro dari pelaku usaha mikro yang memperoleh pinjaman dalam kegiatan pemberdayaan, dan (c) menganalisis tingkat pendapatan pelaku usaha mikro yang memperoleh pinjaman dalam kegiatan pemberdayaan.

\section{Metode Penelitian}

\section{Lokasi dan Waktu Penelitian}

Penelitian ini dilaksanakan di tempat dikembangkannya LKM Posdaya Kenanga, Kelurahan Situ Gede, Kecamatan Bogor Barat, Kota Bogor. Lokasi penelitian ditentukan secara sengaja (purposive) dengan merujuk pada informasi yang diperoleh dari LPPM IPB, internet, dan studi literatur. Lokasi ini dipilih karena Posdaya Kenanga adalah posdaya yang dianggap unggul serta kerap kali menjadi pusat perhatian dan dikunjungi oleh berbagai instansi pemerintah. Pada tanggal 27 Januari 2012, Posdaya Kenanga menerima penghargaan Damandiri Award 2012 dari Yayasan Damandiri.

Kerangka sampling dari penelitian ini adalah pelaku usaha mikro yang menerima kredit mikro dari LKM Posdaya Kenanga. Unit analisis yang digunakan adalah individu yang merupakan pelaku usaha mikro. Responden dipilih dengan menggunakan teknik simple random sampling. Ada 46 orang responden yang diteliti dari jumlah kerangka sampling sebanyak 73 orang.

Data yang digunakan dalam penelitian ini adalah data primer dan data sekunder. Data primer diperoleh dari kuesioner dan wawancara mendalam. Kuesioner ditujukan kepada 46 responden yang merupakan pelaku usahamikroselakupeminjam diLKMPosdayaKenanga. Wawancara mendalam diarahkan kepada informan. Data sekunder berasal dari dokumen-dokumen yang terkait mengenai topik penelitian. Data diperoleh dari studi literatur yang berkaitan dengan tujuan penelitian seperti buku teks, artikel, skripsi, tesis, disertasi, karya ilmiah, dan arsip/dokumen yang berhubungan dengan penelitian, terutama mengenai Kelurahan Situ Gede.
Uji korelasi menggunakan metode Rank Spearman Test, selanjutnya diolah dengan menggunakan Software SPSS 20 For Windows. Nilai koefisien korelasi merupakan nilai yang digunakan untuk mengukur kekuatan (keeratan) suatu hubungan antar variabel. Koefisien korelasi memiliki nilai antara -1 hingga +1 . Sifat nilai koefisien korelasi adalah plus $(+)$ atau minus (-). Hal ini menunjukkan arah korelasi. Selain itu, ada pula keeratan korelasi yang dapat dikelompokkan ke dalam beberapa tingkat sebagai berikut :

1) 0,00 sampai dengan 0,20 berarti korelasi memiliki keeratan sangat lemah.

2) 0,21 sampai dengan 0,40 berarti korelasi memiliki keeratan lemah.

3) 0,41 sampai dengan 0,70 berarti korelasi memiliki keeratan kuat.

4) 0,71 sampai dengan 0,90 berarti korelasi memiliki keeratan sangat kuat.

5) 0,90 sampai dengan 0,99 berarti korelasi memiliki keeratan sangat kuat sekali.

6) 1 berarti korelasi sempurna.

Selanjutnya, pedoman yang digunakan untuk menerima atau menolak hipotesis jika menggunakan hipotesis nol (Ho) yang diusulkan adalah:

1. Ho diterima jika nilai $p$-value kolom sig.(2-tailed) $>$ level of significant $(\alpha)$

2. Ho ditolak jika nilai p-value pada kolom sig. $(2$-tailed) $<$ level of significant $(\alpha)$

3. Ha diterima jika nilai p-value pada kolom sig. $(2$-tailed $)<$ level of significant $(\alpha)$

4. Ha ditolak jika nilai p-value pada kolom sig. $(2$-tailed) $>$ level of significant $(\alpha)$

Taraf nyata yang digunakan dalam penelitian ini adalah 0,01 dan 0,05. Singarimbun dan Effendi (2008) mengatakan bahwa dalam realitas, proses penelitian survei lebih mendekati proses penelitian yang dinamis, sama halnya pada penetapan taraf nyata.

\section{Hasil dan Pembahasan}

\section{Sejarah Pembentukan Posdaya Kenanga}

Posdaya Kenanga terbentuk setelah adanya pelaksanaan kegiatan sosialisasi Posdaya kepada kaderkader di Kelurahan Situ Gede pada tanggal 26April 2010. Setelah diadakannya sosialisasi tersebut, masyarakat 
Tabel 1 Jumlah dan Persentase Pelaku Usaha Mikro Menurut Tingkat Ketepatan Sasaran LKM Posdaya Kenanga di Kelurahan Situ Gede tahun 2013

\begin{tabular}{lcc}
\hline Tingkat Ketepatan Sasaran & Jumlah & Persentase (\%) \\
\hline Tepat & 18 & 39 \\
Tidak tepat & 28 & 61 \\
\hline Total & 46 & 100 \\
\hline
\end{tabular}

setempat setuju dan mendukung untuk pembentukan Posdaya di Kelurahan Situ Gede. Oleh karena itu, pada tanggal 7 Mei 2010 dilaksanakan Lokakarya mini pembentukan Posdaya di Kantor Kelurahan Situ Gede. Pada tanggal 13 Mei 2010 dilaksanakan rapat koordinasi antar Tim Peneliti dengan koordinator Posdaya untuk membahas lokasi (RW) percontohan kegiatan Posdaya. Dari hasil tersebut terpilihlah RW 05 sebagai lokasi percontohan kegiatan Posdaya. Pada tanggal 22 Mei 2010 dilakukan pertemuan dengan masyarakat RW 05 untuk melengkapi kepengurusan Posdaya di tingkat RW 05 dan telah terbentuk susunan pengurus Posdaya di Kelurahan Situ Gede yang diberi nama Posdaya Kenanga.

Posdaya merupakan sebuah gerakan yang mengusung kemandirian dan pemanfaatan sumber daya serta potensi lokal yang ada. Posdaya dikembangkan sebagai salah satu sarana dalam meningkatkan kualitas hidup masyarakat untuk membangun keluarga yang mandiri dan sejahtera. Pembentukan Posdaya Kenanga di kelurahan Situ Gede diharapkan dapat berperan sebagai wadah pelayanan keluarga secara terpadu terutama di bidang pendidikan, kesehatan, ekonomi, dan pengembangan lingkungan yang dapat memudahkan keluarga berkembang secara mandiri dan sejahtera.

\section{Karakteristik Responden}

Responden dalam penelitian ini merupakan masyarakat Kelurahan Situ Gede yang menjalankan usaha mikro dan melakukan pinjaman di LKM Posdaya Kenanga. Sebagian besar pelaku usaha mikro di LKM
Posdaya Kenanga adalah perempuan. Sejalan dengan temuan Goetz dan Gupta (1996) dalam Khander (1998) bahwa sebagian besar partisipan dalam program kredit mikro di banyak negara adalah perempuan. Sebagian besar responden dalam penelitian ini masuk dalam kategori dewasa, sedangkan sisanya adalah orang tua. Usia 15-49 tahun dikategorikan sebagai orang dewasa dan usia 50 tahun ke atas dikategorikan sebagai orang tua. Hasil penelitian menunjukan bahwa seseorang yang berada pada usia produktif lebih banyak melakukan usaha dibanding yang sudah berusia lanjut.

Tingkat pendidikan yang dimiliki oleh seseorang merupakan salah satu faktor penting untuk mengetahui tingkat pengetahuan seseorang. Pengetahuan yang luas membantu seseorang dalam mempertahankan keberlanjutan dan pengembangan usaha. Sebagian besar responden merupakan lulusan SMA dengan persentase sebesar 44\%, disusul dengan lulusan SMP sebesar 33\%, lulusan SD sebesar 13\%, lulusan Universitas sebesar 6\%, dan lulusan Akademi sebesar 4\%.

Jenis usaha yang dimiliki oleh responden terbagi ke dalam 3 jenis, yakni produsen makanan/ minuman, pedagang besar/eceran, danjasa. Responden yang termasuk ke dalam kategori produsen makanan/ minuman adalah individu yang menjual nasi uduk/ gado-gado/soto dan gorengan, penjual kue basah, dan penjual kerupuk yang memproduksi sendiri makanan/ minuman yang dipasarkan dan dijual dengan cara mangkal di suatu tempat, ngider, atau dititipkan di warung. Pedagang besar/eceran adalah individu yang menjual benda kebutuhan sehari-hari dengan jumlah besar atau eceran di warung, toko/kios, mangkal di suatu tempat, atau ngider, seperti warung penjual

Tabel 2 Jumlah dan Persentase Pelaku Usaha Mikro Menurut Tingkat Pemberian Sumberdaya LKM Posdaya Kenanga di Kelurahan Situ Gede Tahun 2013

\begin{tabular}{lcc}
\hline \multicolumn{1}{c}{ Tingkat Pemberian Sumber Daya } & Jumlah & Persentase (\%) \\
\hline Baik & 44 & 96 \\
Tidak baik & 2 & 4 \\
\hline Total & 46 & 100 \\
\hline
\end{tabular}


Jurnal Penyuluhan, September 2013 Vol. 9 No. 2

Tabel 3 Jumlah dan Persentase Pelaku Usaha Mikro menurut Tingkat Pengembangan Gerakan LKM Posdaya Kenanga di Kelurahan Situ Gede Tahun 2013

\begin{tabular}{lcc}
\hline \multicolumn{1}{c}{ Tingkat Pengembangan Gerakan } & Jumlah & Persentase (\%) \\
\hline Baik & 45 & 98 \\
Tidak Baik & 1 & 2 \\
\hline Total & 46 & 100 \\
\hline
\end{tabular}

jajanan, warung sembako, usaha kredit, pedagang sayur-mayur, pedagang buah-buahan, pedagang gas dan listrik, dan pedagang aksesoris Play Station(PS). Individu yang termasuk dalam kategori jasa adalah penyedia layanan cuci motor, penjahit, pengepul rongsokan, dan rental Play Station(PS).

Jumlah anggota keluarga dari responden dibagi menjadi dua kategori, yakni tinggi dan rendah. Pelaku usaha mikro termasuk ke dalam jumlah anggota rumah tangga rendah jika memiliki jumlah anggota keluarga 2-4 orang, sedangkan jumlah anggota rumah tangga tinggi jika memiliki jumlah anggota keluarga lebih dari 5 orang. Kategori ini diukur dengan menggunakan rumus:

$$
(\mathrm{IK})=\frac{\text { skor maksimum }- \text { skor minimun }}{\sum \text { kategori }}
$$

Keterangan : IK $=$ Interval kelas

\section{Implementasi LKM}

Lembaga Keuangan Mikro (LKM) Posdaya Kenanga di Kelurahan Situ Gede didirikan untuk mengatasi masalah kurangnya akses masyarakat terhadap keuangan/modal usaha. Selain itu, bertujuan untuk mengurangi ketergantungan masyarakat terhdap bank keliling. Maraknya bank keliling yang menawarkan pinjaman dengan proses yang cepat membuat masyarakat mengabaikan konsekuensi tingginya bunga pinjaman, karena terdesak akan kebutuhan yang harus segera dipenuhi. Verhagen (1996) dalam Hikmat (2004) merumuskan delapan instrumen untuk menilai implementasi dari kegiatan pemberdayaan masyarakat. Instrumen tersebut dinilai dapat membantu di dalam menyusun suatu program pemberdayaan masyarakat dan memberikan gambaran tentang proses pemberdayaan masyarakat. Instrumen yang dimaksud adalah:

1. Identifikasi kelompok sasaran

Setiap calon program pemberdayaan diseleksi agar tepat sasaran.

2. Penelitian dan perencanaan usaha secara partisipatif

Masyarakat (tidak terkecuali wanita) dilibatkan dalam identifikasi masalah dan perencanaan kegiatan usaha. Hal ini dilakukan agar perencanaan yang dilaksanakan dapat bermanfaat karena telah sesuai dengan kebutuhan, kondisi, serta potensi yang dimiliki.

3. Pendidikan dan pelatihan timbal balik Salah satu penyebab masyarakat tidak berdaya adalah kurangnya pengetahuan serta keterampilan. Oleh karena itu, perlu adanya pendidikan dan pelatihan untuk meningkatkan pengetahuan dan keterampilan masyarakat. Pendidikan dan pelatihan ini hendaknya memperhatikan potensi dan sumber daya lokal.

4. Mobilisasi dan pemberian sumber daya secara seimbang

Pelayanan dan kemudahan akses terhadap sumber daya diperlukan untuk mendukung kegiatan pendidikan dan pelatihan. Selain itu, masyarakat hendaknya juga dibimbing untuk menghimpun modal atau sumber daya secara mandiri.

5. Konsultasi manajemen dan administrasi atau pembukuan

Salah satu kelemahan dari sektor usaha kecil adalah

Tabel 4 Jumlah dan Persentase Pelaku Usaha Mikro menurut Implementasi LKM Posdaya Kenanga di Kelurahan Situ Gede Tahun 2013

\begin{tabular}{|c|c|c|}
\hline Implementasi LKM & Jumlah & Persentase (\%) \\
\hline Baik & 44 & 96 \\
\hline Tidak baik & 2 & 4 \\
\hline Total & 46 & 100 \\
\hline
\end{tabular}


Tabel 5 Jumlah dan Persentase Pelaku Usaha Mikro menurut Tingkat Omset Usaha di Kelurahan Situ Gede Tahun 2013

\begin{tabular}{lcc}
\hline \multicolumn{1}{r}{ Tingkat Omset Usaha } & Jumlah & Persentase (\%) \\
\hline Tinggi & 3 & 7 \\
Rendah & 43 & 93 \\
\hline Total & 46 & 100 \\
\hline
\end{tabular}

lemahnya manajemen dan administrasi usaha sehingga mereka tidak berkembang. Oleh karena itu, pembinaan dan pengarahan di dalam mengelola kegiatan usaha harus dilakukan. Dengan demikian, mereka akan belajar bagaimana mengatur manajemen usahanya.

6. Pengembangan gerakan dan perluasan proses

Kegiatan pemberdayaan masyarakat diharapkan dapat menjangkau banyak sasaran, sehingga dibutukan peran aktif dari berbagai pihak.

7. Pengembangan jaringan dengan pihak ketiga di luar LSM dan kelompok

Pembinaan hubungan kemitraan dengan pihak lain diperlukan agar usaha kelompok sasaran dapat berkembang, misalnya lembaga keuangan, lembaga pemasaran, perusahaan, dan pihak lain.

8. Evaluasi terus-menerus sebagai upaya untuk menciptakan mekanisme umpan balik.

Evaluasi baik terhadap strategi, metode, dan kinerja sangat diperlukan karena dapat dimanfaatkan untuk mengetahui proses perencanaan, pelaksanaan, efek, dan dampak yang ditimbulkan. Dengan demikian, dapat diketahui hal penting yang seharusnya diperbaiki dalam perencanaan selanjutnya.

Implementasi LKM dalam penelitian ini diukur dengan tiga indikator, yakni tingkat ketepatan sasaran, tingkat pemberian sumber daya, dan tingkat pengembangan gerakan. Tingkat ketepatan sasaran dilihat dari karakteristik peminjam yang termasuk masyarakat miskin atau berpenghasilan rendah. Selanjutnya, tingkat fleksibilitas prosedur dilihat dari proses dan prosedur Tingkat pemberian sumber daya dilihat dari fasilitas yang disediakan oleh LKM dan sikap dari petugas LKM. Selanjutnya, tingkat pengembangan gerakan dilihat dari banyaknya sasaran yang dijangkau dalam kegiatan pemberdayaan.

Sasaran dari penerima kredit mikro adalah masyarakat miskin atau berpenghasilan rendah. Kategori miskin dan berpenghasilan rendah dilihat dari jenis bantuan pemerintah yang diterima oleh pelaku usaha mikro, yakni memperoleh bantuan raskin dan memiliki jamkesmas/jamkesda. Adanya kredit mikro ini diharapkan dapat membantu mereka untuk meningkatkan pendapatan. Perubahan tingkat pendapatan tentunya akan mempengaruhi taraf hidup masyarakat itu sendiri. Hasil penelitian menunjukkan bahwa sasaran dari penerima usaha mikro sebagian besar masih kurang tepat. Sebanyak 61\% pelaku usaha mikro yang menerima pinjaman masuk dalam kategori tidak tepat karena tidak termasuk sebagai masyarakat yang memperoleh bantuan raskin dan tidak memiliki jamkesmas/jamkesda. Selebihnya $39 \%$ masuk dalam kategori tepat karena memperoleh bantuan raskin dan memiliki jamkesmas/jamkesda. Adams et al. (1984) dalam Zeller et al. (1997) mengungkapkan bahwa persyaratan agunan, lembar kerja/usaha, proses yang lama, korupsi, dan penagih pinjaman telah banyak membuat peminjam yang merupakan masyarakat miskin cukup ketakutan untuk memperoleh kredit formal. Pemberian sumber daya secara seimbang akan mempengaruhi transaksi keuangan pelaku usaha mikro di LKM. Pelayanan dan kemudahan akses terhadap sumber daya

Tabel 6 Jumlah dan Persentase Pelaku Usaha Mikro menurut Tingkat Aset Usaha di Kelurahan Situ Gede Tahun 2013

\begin{tabular}{|c|c|c|}
\hline Tingkat Aset Usaha & Jumlah & Persentase (\%) \\
\hline Tinggi & 3 & 7 \\
\hline Rendah & 43 & 93 \\
\hline Total & 46 & 100 \\
\hline
\end{tabular}


Jurnal Penyuluhan, September 2013 Vol. 9 No. 2

Tabel 7 Jumlah dan Persentase Pelaku Usaha Mikro menurut Pengembangan Usaha Mikro di Kelurahan Situ Gede Tahun 2013

\begin{tabular}{lcc}
\hline \multicolumn{1}{c}{ Pengembangan Usaha Mikro } & Jumlah & Persentase (\%) \\
\hline Tinggi & 2 & 4 \\
Rendah & 44 & 96 \\
\hline Total & 46 & 100 \\
\hline
\end{tabular}

sangat dibutuhkan oleh pelaku usaha mikro. Hasil penelitian menunjukkan bahwa tingkat pemberian sumber daya LKM Posdaya Kenanga masuk dalam kategori baik.

Sebanyak $4 \%$ pelaku usaha mikro yang menyatakan tingkat pemberian sumber daya tidak baik disebabkan kurangnya informasi terhadap penjelasan mengenai fasilitas yang disediakan oleh LKM Posdaya Kenanga kepada pelaku usaha mikro. Petugas LKM belum memberikan penjelasan yang terperinci, sehingga beberapa responden masih belum mengetahui dan memahami secara detil mengenai fungsi dan jenisjenis dari tabungan yang disediakan oleh LKM.

Kegiatan pemberdayaan terhadap masyarakat diharapkan dapat menjangkau banyak sasaran. LKM sudah seharusnya mengutamakan pemberian kredit mikro kepada masyarakat selaku pelaku usaha mikro di lokasi sekitar, tempat dibentuknya LKM. Hasil penelitian menunjukkan bahwa tingkat pengembangan gerakan LKM Posdaya Kenanga masuk dalam kategori baik. Hal ini disebabkan LKM Posdaya Kenanga telah menjangkau banyak sasaran dari kalangan pelaku usaha mikro di Kelurahan Situ Gede.

Mengacu pada data setiap variabel dapat ditarik kesimpulan bahwahampir seluruh pelaku usaha mikro menganggap implementasi LKM Posdaya Kenanga masuk dalam kategori baik. Implementasi LKM Posdaya Kenanga dikatakan baik karena dari hasil tabel frekuensi menunjukkan tingkat ketepatan sasaran, tingkat pemberian sumber daya, dan tingkat pengembangan gerakan masuk dalam kategori tepat dan baik. Selain itu, dibuktikan dengan hasil tabel frekuensi implementasi LKM secara keseluruhan, yang menunjukkan sebanyak $96 \%$ pelaku usaha mikro menyatakan bahwa implementasi LKM masuk dalam kategori baik karena telah sesuai dengan sasaran dan tujuan yang telah ditetapkan sebelumnya.

\section{Pengembangan Usaha Mikro}

Tersedianya pelayanan keuangan terhadap masayarakat miskin adalah salah satu cara untuk membantu meningkatkan pendapatan dan produktivitas mereka. Kredit mikro dan program kerjasama sudah dibentuk untuk mengisi kelangkaan ini. Tujuannya adalah untuk membantu masayarakat miskin menjadi self employed dan keluar dari garis kemiskinan (Khandker, 1998). Pengembangan usaha mikro dalam penelitian ini dianalisis dari jumlah omset dan nilai aset usaha, di luar tanah dan bangunan. Merujuk pada hipotesis penelitian, diduga terdapat hubungan antara pengembangan usaha dengan tingkat pendapatan pelaku usaha mikro.

Omset adalah hasil penjualan atau pendapatan yang diperoleh dari suatu usaha dalam satu bulan. Pada penelitian ini omset merupakan salah satu alat ukur dalam melihat pengembangan usaha. Hasil penelitian menunjukkan bahwa sebagian besar pelaku usaha mikro memiliki omset yang rendah. Sebanyak $7 \%$ pelaku usaha mikro memiliki omset yang tinggi, selebihnya sebanyak 93\% pelaku usaha mikro masih memiliki omset yang rendah. Pelaku usaha mikro yang termasuk dalam kategori kepemilikan omset rendah jika memperoleh omset setiap bulannya sebesar Rp $245.000-\leq$ Rp 22.622.500, sedangkan yang termasuk dalam kategori tinggi jika memiliki

Tabel 8 Persentase Hubungan Tingkat Ketepatan Sasaran dengan Tingkat Omset Usaha Tahun 2013

\begin{tabular}{lccc}
\hline \multirow{2}{*}{ Tingkat Ketepatan Sasaran } & \multicolumn{2}{c}{ Tingkat Omset Usaha (\%) } & \multirow{2}{*}{ Total (\%) } \\
\hline Tidak tepat & 89 & 11 & 100 \\
Tepat & 100 & 0 & 100 \\
\hline
\end{tabular}


Tabel 9 Persentase Hubungan Tingkat Ketepatan Sasaran dengan Tingkat Aset Usaha Tahun 2013

\begin{tabular}{lccc}
\hline \multirow{2}{*}{ Tingkat Ketepatan Sasaran } & \multicolumn{2}{c}{ Tingkat Aset Usaha (\%) } & \multirow{2}{*}{ Total (\%) } \\
\cline { 2 - 3 } & Rendah & Tinggi & \\
\hline Tidak tepat & 89 & 11 & 100 \\
Tepat & 100 & 0 & 100 \\
\hline
\end{tabular}

omset sebesar > Rp 22.622.500 - Rp 45.000.000 setelah memperoleh pinjaman.

Asetadalah benda ataubarangyang dibutuhkan oleh individu untuk menjalankan usaha, seperti alat produksi dan distribusi usaha. Pengembangan atau inovasi usaha dapat dilakukan jika aset yang dimiliki bertambah ataupun memiliki alat yang lebih modern. Hasil penelitian menunjukkan bahwa sekitar 93\% pelaku usaha mikro memiliki aset yang rendah, sedangkan $7 \%$ pelaku usaha mikro memiliki aset yang tinggi. Pelaku usaha mikro yang termasuk dalam kategori kepemilikan aset rendah jika memiliki nilai aset sebesar $\mathrm{Rp} 0-\leq \mathrm{Rp} 2.340 .000$, sedangkan yang termasuk dalam kategori tinggi jika memiliki aset sebesar $>\operatorname{Rp} 2.340 .000-\operatorname{Rp} 4.680 .000$ setelah memperoleh pinjaman.

Pengembangan usaha mikro dalam penelitian ini dianalisis dari jumlah omset usaha setiap bulan dan nilai aset usaha yang dimiliki oleh pelaku usaha mikro setelah memperoleh pinjaman. Mengacu pada data di atas dapat dilihat bahwa sebanyak $4 \%$ pelaku usaha mikro mengalami peningkatan pengembangan usaha, sedangkan sebanyak $96 \%$ pelaku usaha mikro tidak mengalami peningkatan pengembangan usaha. Tingginya pengembangan usaha mikro dipengaruhi oleh tingginya jumlah omset usaha dan nilai aset usaha yang dimiliki pelaku usaha mikro.

Sebanyak 26\% pelaku usaha mikro adalah produsen makanan/minuman, 59\% pedagang besar/ eceran, dan $15 \%$ penyedia jasa. Individu-individu pelaku usaha mikro tidak hanya berjualan di sekitar Kelurahan Situ Gede, tetapi ada juga yang berjualan di luarlingkungan setempat.Pemilihanlokasiperdagangan ditentukan berdasarkan perkiraan kemampuan dan peluang responden dalam memperoleh keuntungan secara materil (laba).

\section{Hubungan Tingkat Ketepatan Sasaran dengan Tingkat Omset Usaha}

Tingkat ketepatan sasaran yang tinggi dilihat dari karakteristik peminjam, yakni masyarakat miskin atau berpenghasilan rendah. Sebanyak $61 \%$ responden yang memperoleh pinjaman dari LKM Posdaya Kenanga masuk dalam kategori tepat, sisanya sebanyak 39\% masuk dalam kategori tepat (Tabel 8).

Hasilujikorelasi Rank Spearmanmenghasilkan koefisien korelasi sebesar -0,212 dan sig. (2-tailed) sebesar 0,158. Ini artinya tingkat ketepatan sasaran dengan tingkat omset usaha pelaku usaha mikro tidak berhubungan nyata karena nilai sig. (2-tailed) sebesar $0,158>0,05$ (level of significant) dengan keeratan hubungan sangat lemah.

Rendahnya omset usaha pelaku usaha mikro disebabkan tingginya persaingan usaha sejenis pada kasus usaha warung penjual jajanan. Selain itu, harga bahan baku yang tidak stabil pada kasus usaha pengepul rongsokan turut mempengaruhi rendahnya omset usaha.

\section{Hubungan Tingkat Ketepatan Sasaran dengan Tingkat Aset Usaha}

Sebagian besar responden masih memiliki nilai aset yang rendah. Sebanyak 93\% responden masih memiliki nilai aset yang rendah, sisanya sebanyak $7 \%$ responden memiliki nilai aset yang tinggi (Tabel 9). Hasil uji korelasi Rank Spearman menghasilkan koefisien korelasi sebesar -0,212 dan sig. (2-tailed)

Tabel 10 Persentase Hubungan Pemberian Sumberdaya dengan Tingkat Omset Usaha Tahun 2013

\begin{tabular}{lccc}
\hline \multicolumn{1}{c}{ Tingkat Pelayanan Keuangan } & \multicolumn{2}{c}{ Tingkat Omset Usaha (\%) } & \multirow{2}{*}{ Total (\%) } \\
& Rendah & Tinggi & \\
\hline Tidak baik & 100 & 0 & 100 \\
Baik & 93 & 7 & 100 \\
\hline
\end{tabular}


Jurnal Penyuluhan, September 2013 Vol. 9 No. 2

Tabel 11 Persentase Hubungan Tingkat Pemberian Sumberdaya dengan Tingkat Aset Usaha Tahun 2013

\begin{tabular}{lccc}
\hline \multirow{2}{*}{ Tingkat Pelayanan Keuangan } & \multicolumn{2}{c}{ Tingkat Aset Usaha (\%) } & Total (\%) \\
& Rendah & Tinggi & 100 \\
\hline Tidak baik & 100 & 0 & 100 \\
Baik & 93 & 7 & \\
\hline
\end{tabular}

sebesar 0,158, artinya tingkat ketepatan sasaran dengan tingkat nilai aset usaha pelaku usaha mikro tidak berhubungan nyata karena nilai sig. (2-tailed) sebesar $0,158>0,05$ (level of significant) dengan keeratan hubungan sangat lemah.

Sebagian besar responden masih memiliki aset yang rendah karena usaha yang mereka geluti adalah produksi makanan/minuman, sehingga aset yang digunakan adalah alat-alat sederhana. Selain itu, beberapa responden juga menggeluti usaha kredit pakaian, sehingga tidak membutuhkan peralatan dan alat distribusi. Proses jual-beli cukup dengan menawarkan ke tetangga, ibu-ibu di tempat anak bersekolah, ataupun menitipkan dagangan kepada saudara yang bekerja di pabrik.

\section{Hubungan Tingkat Pemberian Sumber Daya dengan Tingkat Omset Usaha}

Sebanyak $100 \%$ responden yang menyatakan tingkat pemberian sumber daya tidak baik memiliki omset yang rendah. Responden yang menyatakan tingkat pemberian sumber daya baik dan memiliki omset yang rendah berjumlah 93\%, sedangkan responden yang menyatakan tingkat pemberian sumber daya baik dan memiliki omset yang tinggi berjumlah 7\%. Hasil uji korelasi dengan menggunakan Rank Spearmanmenghasilkan nilai koefisien korelasi sebesar 0,056, lalu nilai sig. (2-tailed) sebesar 0,710. Ini menunjukkan bahwa tingkat pemberian sumber daya dengan tingkat omset usaha dari pelaku usaha mikro tidak berhubungan nyata karena nilai sig. (2-tailed) sebesar 0,710 >0,05 (level of significant) dengan keeratan hubungan sangat lemah.
Omset yang diperoleh pelaku usaha mikro sebagian besar rendah disebabkan oleh beberapa hal, seperti kurangnya jumlah tenaga kerja pada kasus usaha produsen makanan/minuman, tingginya persaingan produk sejenis pada kasus usaha warung penjual jajanan, dan tempat pemasaran yang kecil pada kasus usaha kredit pakaian. Pada kasus responden yang memiliki jumlah omset yang tinggi disebabkan pengembangan usahanya sudah baik dan tingkat persaingan yang relatif rendah, seperti warung sembako.

\section{Hubungan Tingkat Pemberian Sumber Daya dengan Tingkat Aset Usaha}

Sebagian besar pelaku usaha mikro masih memiliki nilai aset usaha yang rendah, meskipun tingkat pemberian sumber daya yang ditawarkan oleh LKM sudah baik. Sebanyak 100\% responden yang menyatakan tingkat pemberian sumber daya LKM tidak baik dan 93\% responden yang menyatakan tingkat pemberian sumber daya baik masih memiliki nilai aset usaha yang rendah (Tabel 11). Hasil uji korelasi Rank Spearmanmenghasilkan koefisien korelasi sebesar 0,056 dan sig. (2-tailed) sebesar 0,710. Ini menunjukkan bahwa tingkat pemberian sumber daya dengan tingkat nilai aset usaha pelaku usaha mikro tidak berhubungan nyata karena nilai sig. (2-tailed) sebesar 0,710>0,05 (level of significant) dengan keeratan hubungan sangat lemah.

Nilai aset usaha pelaku usaha mikro rendah disebabkan aset yang lama masih dalam kondisi yang bagus dan layak pakai. Selain itu, responden

Tabel 12 Persentase Hubungan Tingkat Pengembangan Gerakan dengan Tingkat Omset Usaha Tahun 2013

\begin{tabular}{lccc}
\hline \multicolumn{1}{c}{ Tingkat Fleksibilitas Prosedur } & \multicolumn{2}{c}{ Tingkat Omset Usaha (\%) } & \multirow{2}{*}{ Total (\%) } \\
& Rendah & Tinggi & 100 \\
Tidak fleksibel & 100 & 0 & 100 \\
Fleksibel & 93 & 7 & \\
\hline
\end{tabular}


Tabel 13 Persentase Hubungan Tingkat Pengembangan Gerakan dengan Tingkat Aset Usaha Tahun 2013

\begin{tabular}{lccc}
\hline \multirow{2}{*}{ Tingkat Fleksibilitas Prosedur } & \multicolumn{2}{c}{ Tingkat Aset Usaha (\%) } & \multirow{2}{*}{ Total (\%) } \\
& Rendah & Tinggi & \\
\hline Tidak Fleksibel & 100 & 0 & 100 \\
Fleksibel & 93 & 7 & 100 \\
\hline
\end{tabular}

juga menambahkan bahwa alat-alat yang mereka butuhkan cukup sederhana.

\section{Hubungan Tingkat Pengembangan Gerakan dengan Tingkat Omset Usaha}

Tingkat pengembangan gerakan dilihat dari banyaknya sasaran dari kalangan pelaku usaha mikro di Kelurahan Situ Gede yang dijangkau oleh LKM Posdaya Kenanga. Seluruh responden menyatakan bahwa banyaknya sasaran dari kalangan pelaku usaha mikro di Kelurahan Situ Gede masuk dalam kategori baik, berdasarkan tabel frekuensi tingkatpengembangan gerakan pada Tabel 7.

Hasil uji korelasi Rank Spearmanmenghasilkan koefisien korelasi sebesar 0,039 dan sig. (2-tailed) sebesar 0,795. Ini menunjukkan bahwa tingkat pengembangan gerakan dengan tingkat omset usaha pelaku usaha mikro tidak berhubungan karena nilai sig. (2-tailed) sebesar 0,795 >0,05 (level of significant) dengan keeratan hubungan sangat lemah. Tingkat pengembangan gerakan di LKM Posdaya Kenanga tidak mempengaruhi tingginya omset usaha pelaku usaha mikro. Ini disebabkan rendahnya jumlah pinjaman yang diberikan berkisar Rp 1.500.000 - Rp 2.000.000. Jumlah pinjaman yang rendah tidak mencukupi bagi responden untuk membeli aset usaha pada kasus penjual sayurmayur dan penjual buah-buahan.

\section{Hubungan Tingkat Pengembangan Gerakan dengan Tingkat Aset Usaha}

Banyaknya sasaran yang dijangkau oleh LKM Posdaya Kenanga sudah baik. Sebanyak 98\% responden yang menyatakan banyaknya sasaran yang dijangkau dari kalangan pelaku usaha mikro masuk dalam kategori baik, sedangkan sisanya sebanyak 2 persen menyatakan masuk dalam kategori tidak baik. Hasil uji korelasi Rank Spearman menghasilkan koefisien korelasi sebesar 0,039 dan sig. (2-tailed) sebesar 0,795. Ini menunjukkan bahwa tingkat pengembangan gerakan dengan tingkat nilai aset usaha pelaku usaha mikro tidak berhubungan karena nilai sig. (2-tailed) sebesar 0,795 >0,05 (level of significant) dengan keeratan hubungan sangat lemah.

Rendahnya nilai aset usaha responden dipengaruhi oleh rendahnya jumlah pinjaman yang tidak mencukupi untuk membeli peralatan, pada kasus penjual sayur-mayur dan penjual buah-buahan. Di samping itu, sebagian besar pelaku usaha mikro tidak memiliki nilai aset usaha yang tinggi karena hanya menggunakan alat-alat sederhana, seperti panci, kompor, dan penggorengan pada kasus produsen makanan/minuman. Ada pula beberapa pelaku usaha mikro yang menggeluti usaha kredit pakaian, sehingga tidak membutuhkan alat-alat produksi dan distribusi usaha. Usaha cukup dilakukan dengan menawarkan barang-barang dagangan kepada warga yang berminat untuk membeli atau menawarkan kepada seorang pembeli agar ditawarkan kepada calon pembeli lainnya ( word of mouth).

\section{Hubungan Implementasi LKM dengan Pengembangan Usaha Mikro}

Implementasi LKM Posdaya Kenanga secara keseluruhan masuk dalam kategori baik. Sebanyak

Tabel 14 Persentase Hubungan Implementasi LKM dengan Pengembangan Usaha Mikro Responden Tahun 2013

\begin{tabular}{lccc}
\hline \multirow{2}{*}{ Implementasi LKM } & \multicolumn{2}{c}{ Pengembangan Usaha Mikro (\%) } & Total (\%) \\
& Rendah & Tinggi & 100 \\
Tidak baik & 100 & 0 & 100 \\
Baik & 95 & 5 & \\
\hline
\end{tabular}


Tabel 15 Persentase Hubungan Tingkat Omset Usaha dengan Tingkat Pendapatan Pelaku Usaha Mikro tahun 2013

\begin{tabular}{lccc}
\hline Tingkat Omset Usaha & $\begin{array}{c}\text { Tingkat Pendapatan Pelaku Usaha Mikro (\%) } \\
\text { Rendah }\end{array}$ & $\begin{array}{c}\text { Total } \\
\text { Tinggi }\end{array}$ \\
\hline Rendah & 86 & 14 & 100 \\
Tinggi & 33 & 67 & 100 \\
\hline
\end{tabular}

96\% responden menyatakan implemenasi LKM masuk dalam kategori baik, sisanya sebanyak $4 \%$ menyatakan implementasi LKM masuk dalam kategori tidak baik, lebih lengkapnya dapat dilihat pada Tabel 8. Sebaliknya, pengembangan usaha mikro secara keseluruhan masuk dalam kategori rendah. Sebanyak 4\% responden masuk dalam kategori pengembangan usaha yang tinggi, selebihnya sebanyak $96 \%$ masuk dalam kategori pengembangan usaha rendah. Data di atas menunjukkan secara garis besar implementasi LKM dengan pengembangan usaha mikro tidak berhubungan. Ini diperkuat dengan hasil uji korelasi Rank Spearmanyang menunjukkan koefisien korelasi sebesar 0,045 dan sig. (2-tailed) sebesar 0,764. Ini berarti implementasi LKM dengan pengembangan usaha mikro pelaku usaha mikro tidak berhubungan karena nilai sig. (2-tailed) sebesar 0,764 >0,05 (level of significant) dengan keeratan hubungan sangat lemah.

Semakin baik implementasi LKM ternyata tidak mempengaruhi terhadap peningkatan pengembangan usaha mikro. Ini disebabkan oleh beberapa faktor. Pertama, kurangnya jumlah tenaga kerja yang menyebabkan hasil produksi tidak optimal, sehingga berdampak terhadap omset usaha yang diperoleh. Kedua, tingginya persaingan produk sejenis menyebabkan berkurangnya penjualan.

Ketiga, tempat pemasaran dengan ruang lingkup yang kecil menyebabkan kurang luasnya lokasi penjualan. Keempat, sedikitnya jumlah pinjaman yang berkisar Rp 1.000.000 - Rp 2.000.000 tidak mencukupi untuk modal pengembangan usaha mikro. Kelima, kondisi aset yang masih layak menyebabkan responden tidak membutuhkan aset baru atau tambahan. Keenam, alat-alat yang digunakan cukup sederhana dan masih dalam kondisi yang layak pakai.

\section{Hubungan Tingkat Omset Usaha dengan Tingkat Pendapatan Pelaku Usaha Mikro}

Omset usaha yang meningkat seharusnya mempengaruhi tingkat pendapatan usaha. Hasil penelitian menunjukkan bahwa sebagian besar tingkat pendapatan pelaku usaha mikro masih rendah. Sebanyak $86 \%$ pelaku usaha mikro yang masuk dalam kategori kepemilikan omset yang rendah memperoleh pendapatan yang rendah, sisanya sebanyak 14\% pelaku usaha mikro memperoleh pendapatan yang tinggi. Selanjutnya, sebanyak $33 \%$ pelaku usaha mikro yang masuk dalam kategori kepemilikan omset yang tinggi memperoleh pendapatan yang rendah, sisanya sebanyak $67 \%$ pelaku usaha mikro memperoleh pendapatan yang tinggi.

Hasilujikorelasi Rank Spearmanmenghasilkan koefisin korelasi sebesar $0,576^{* *}$. Ini menunjukkan bahwa tingkat omset usaha dengan tingkat pendapatan pelaku usaha mikro berhubungan positif dan sangat nyata karena nilai sig. (2-tailed) sebesar $0,000<0,01$ (level of significant) dengan keeratan hubungan kuat. Semakin tinggi omset usaha maka semakin tinggi pula pendapatan pelaku usaha mikro begitu pula sebaliknya.

Pendapatan pelaku usaha mikro yang rendah disebabkan pemilihan lokasi usaha perdagangan yang kurang tepat. Pembeli di sekitar lokasi usaha yang baru tidak seramai di lokasi usaha pertama, sehingga pelaku usaha mikro mengalami kerugian. Kerugian dari lokasi usaha baru harus ditutupi dengan keuntungan yang diperoleh dari lokasi usaha pertama.

Beberapa pelaku usaha mikro lainnya ada pula

Tabel 16 Persentase Hubungan Tingkat Aset Usaha dengan Tingkat Pendapatan Pelaku Usaha Mikro Tahun 2013

\begin{tabular}{lccc}
\hline \multirow{2}{*}{ Tingkat Aset Usaha } & $\begin{array}{c}\text { Tingkat Pendapatan Pelaku Usaha Mikro (\%) } \\
\text { Rendah }\end{array}$ & Tinggi & Total (\%) \\
\hline Rendah & 86 & 14 & 100 \\
Tinggi & 33 & 67 & 100 \\
\hline
\end{tabular}


Tabel 17 Persentase Hubungan Pengembangan Usaha Mikro dengan Tingkat Pendapatan Pelaku Usaha Mikro Tahun 2013

\begin{tabular}{lccc}
\hline \multicolumn{1}{c}{$\begin{array}{c}\text { Pengembangan Usaha } \\
\text { Mikro }\end{array}$} & \multicolumn{2}{c}{ Tingkat Pendapatan Pelaku Usaha Mikro } & Total (\%) \\
& Rendah & Tinggi & \\
\hline Rendah & 86 & 14 & 100 \\
Tinggi & 0 & 100 & 100 \\
\hline
\end{tabular}

yang mengalami peningkatan pendapatan. Tingginya pendapatan pelaku usaha mikro ini disebabkan usahanya sudah cukup berkembang dan memiliki modal awal yang besar, seperti warung makan dan warung sembako.

\section{Hubungan Tingkat Aset Usaha dengan Tingkat Pendapatan Pelaku Usaha Mikro}

Sebagian besar pelaku usaha mikro masih memilikipendapatan yang rendah. Sebanyak $86 \%$ pelaku usaha mikro yang masuk dalam kategori kepemilikan nilai aset yang rendah memperoleh pendapatan yang rendah, sisanya sebanyak $14 \%$ pelaku usaha mikro memperoleh pendapatan yang tinggi. Selanjutnya, $33 \%$ pelaku usaha mikro yang masuk dalam kategori kepemilikan aset yang tinggi memperoleh pendapatan yang rendah, sisanya sebanyak $67 \%$ pelaku usaha mikro memperoleh pendapatan yang tinggi.

Hasilujikorelasi Rank Spearmanmenunjukkan nilai kofisien korelasi sebesar 0,343* dan sig. (2-tailed) sebesar 0,019. Ini artinya tingkat nilai aset usaha dengan tingkat pendapatan pelaku usaha mikro memiliki hubungan positif dan nyata karena nilai sig. (2-tailed) sebesar 0,019 < 0,05 (level of significant) dengan keeratan hubungan lemah. Semakin tinggi nilai aset usaha maka semakin tinggi pula pendapatan pelaku usaha mikro begitu pula sebaliknya.

Rendahnya pendapatan pelaku usaha mikro disebabkan alat-alat yang digunakan oleh beberapa responden cukup sederhana. Selain itu, responden juga menambahkan bahwa alat-alat yang dimiliki masih dalam kondisi yang bagus dan layak pakai.

\section{Hubungan Pengembangan Usaha Mikro dengan Tingkat Pendapatan Pelaku Usaha Mikro}

Pengembangan ekonomi rakyat ditujukan untuk meningkatkan kesejahteraan rakyat. Prinsip dasarnya adalah untuk mengembangkan kemampuan rakyat secara mandiri dalam berusaha mencapai peningkatan kesejahteraannya. Pendekatan utamanya adalah apresiasi terhadap kedaulatan dan kemampuan rakyat itu sendiri, dilanjutkan dengan usaha untuk memperkuat dan meningkatkan keberdayaannya. Daya saing, peningkatan produktivitas, efisiensi, penguasaan pasar, atau peubah ekonomi lainnya hanya merupakan indikator-indikator antara menuju tujuan akhir keberlanjutan kegiatan ekonomi rakyat, peningkatan kemandirian, dan akhirnya peningkatan kesejahteraan rakyat secara keseluruhan (Krisnamurthi, 2002).

Sebanyak $86 \%$ pelaku usaha mikro yang memiliki pengembangan usaha mikro yang rendah memperoleh pendapatan yang rendah, sisanya sebanyak 14\% pelaku usaha mikro memperoleh pendapatan yang tinggi. Pelaku usaha mikro yang memiliki pengembangan usaha mikro yang tinggi dan memperoleh pendapatan yang tinggi ada sebanyak $100 \%$.

Hasil uji korelasi dengan Rank Spearman menghasilkan koefisien korelasi sebesar $0,465 * *$ dan sig. (2-tailed) sebesar 0,001. Ini artinya pengembangan usaha mikro dengan tingkat pendapatan pelaku usaha mikro berhubungan positif dan sangat nyata karena nilai sig. (2-tailed) sebesar 0,001 <0,01 (level of

Tabel 18 Persentase Hubungan Tingkat Ketepatan Sasaran dengan Tingkat Pendapatan Pelaku Usaha Mikro Tahun 2013

\begin{tabular}{lccc}
\hline \multicolumn{1}{c}{ Tingkat Ketepatan Sasaran } & \multicolumn{2}{c}{ Tingkat Pendapatan Pelaku Usaha Mikro (\%) } \\
Rendah & Tinggi & Total (\%) \\
\hline Tidak tepat & 71 & 29 & 100 \\
Tepat & 94 & 6 & 100 \\
\hline
\end{tabular}


Tabel 19 Persentase Hubungan Tingkat Pemberian Sumberdaya dengan Tingkat Pendapatan Pelaku Usaha Mikro Tahun 2013

\begin{tabular}{lccc}
\hline Tingkat Pemberian Sumber Daya & $\begin{array}{c}\text { Tingkat Pendapatan Pelaku Usaha Mikro (\%) } \\
\text { Rendah }\end{array}$ & Total (\%) \\
\hline Tidak baik & 100 & 0 & 100 \\
Baik & 82 & 18 & 100 \\
\hline
\end{tabular}

significant dengan keeratan hubungan kuat. Semakin tinggi pengembangan usaha mikro maka semakin tinggi pula pendapatan pelaku usaha mikro begitu pula sebaliknya, semakin tinggi pengembangan usaha mikro maka semakin tinggi pula pendapatan pelaku usaha mikro.

Pendapatan pelaku usaha mikro sebagian besar rendah disebabkan oleh beberapa faktor. Pertama, pemilihan lokasi usaha yang kurang tepat. Kedua, aset yang digunakan oleh pelaku usaha mikro hanya menggunakan alat-alat sederhana berupa alat-alat masak dan perabotan rumah tangga. Ketiga, mahalnya harga aset peralatan usaha bagi sebagian kecil pelaku usaha mikro.

\section{Hubungan Tingkat Ketepatan Sasaran dengan Tingkat PendapatanPelaku Usaha Mikro}

Awalnya kredit mikro memang ditujukan untuk masyarakat miskin atau berpenghasilan rendah. Oleh karena itu, penyaluran kredit mikro yang tepat sasaran diharapkan dapat membantu meningkatkan pendapatan pelaku usaha mikro. Pelaku usaha mikro yang masuk dalam kategori tepat sasaran adalah individu yang menerima bantuan raskin dan memiliki jamkesmas/jamkesda. Hasil uji korelasi Rank Spearman menunjukkan koefisien korelasi sebesar 0,250 dan sig. (2-tailed) sebesar 0,093. Ini berarti tingkat ketepatan sasaran dengan tingkat pendapatan pelaku usaha mikro tidak berhubungan karena nilai korelasi sebesar 0,093 dengan keeratan hubungan lemah.

Rendahnya pendapatan pelaku usaha mikro disebabkan tidak adanya pembukuan pemasukan dan pengeluran hasil usaha dan tinginya persaingan usaha sejenis. Sebanyak 59\% pelaku usaha mikro adalah pedagang besar/eceran yang terbagi dalam beberapa jenis usaha, yang mana sebagian besar dari mereka menggeluti usaha kredit dan warung penjual jajanan.

\section{Hubungan Tingkat Pemberian Sumber Daya dengan Tingkat Pendapatan Pelaku Usaha Mikro}

Pelayanan keuangan terhadap masyarakat miskin adalah salah satu cara untuk membantu meningkatkan pendapatan dan produktivitas mereka (Khandker, 1998). Oleh karena itu, dengan tingkat pelayanan yang baik diharapkan dapat membantu meningkatkan pendapatan masyarakat. Sebanyak 100\% pelaku usaha mikro menyatakan tingkat pemberian sumber daya tidak baik, memperoleh pendapatan yang rendah. Pelaku usaha mikro yang menyatakan tingkat pemberian sumber daya baik dan memperoleh pendapatan yang rendah ada sebanyak $82 \%$, selebihnya $18 \%$ memperoleh pendapatan yang tinggi.

Hasil uji korelasi Rank Spearman menghasilkan koefisien korelasi sebesar 0,098 dan sig. (2-tailed) sebesar 0,598. Ini berarti tingkat pemberian sumber daya dengan tingkat pendapatan pelaku usaha mikro tidak berhubungan karena nilai sig. (2-tailed) sebesar 0,598 >0,05 (level of significant) dengan keeratan hubungan sangat lemah.

Pendapatan yang diperoleh pelaku usaha mikro rendah disebabkan tidak adanya pembukuan pemasukan dan pengeluaran usaha. Selebihnya, pelaku

Tabel 20 Persentase Hubungan Tingkat Pengembangan Gerakan dengan Tingkat Pendapatan Pelaku Usaha Mikro Tahun 2013

\begin{tabular}{lccc}
\hline \multicolumn{1}{c}{ Tingkat Pengembangan Gerakan } & $\begin{array}{c}\text { Tingkat Pendapatan Pelaku Usaha Mikro (\%) } \\
\text { Rendah }\end{array}$ & Tinggi & Total (\%) \\
\hline Tidak baik & 0 & 100 & 100 \\
Baik & 84 & 16 & 100 \\
\hline
\end{tabular}


Tabel 21 Persentase Hubungan Implementasi LKM dengan Tingkat Pendapatan Pelaku Usaha Mikro Tahun 2013

\begin{tabular}{lccc}
\hline Implementasi LKM & $\begin{array}{c}\text { Tingkat Pendapatan Pelaku Usaha Mikro (\%) } \\
\text { Rendah }\end{array}$ & Total (\%) \\
\hline Tidak baik & 50 & 50 & 100 \\
Baik & 84 & 16 & 100 \\
\hline
\end{tabular}

usaha mikro yang memperoleh pendapatan yang tinggi disebabkan pengembangan usaha mikro yang sudah cukup baik dan memiliki modal awal yang besar di awal usaha, seperti pada kasus usaha warung sembako yang dapat berkembang karena memang telah memiliki modal awal yang besar.

\section{Hubungan Tingkat Pengembangan Gerakan dengan Tingkat PendapatanPelaku Usaha Mikro}

Tingkat pengembangan gerakan di LKM Posdaya Kenanga secara keseluruhan sudah baik. Sebanyak $84 \%$ pelaku usaha mikro yang menyatakan banyaknya sasaran dari kalangan pelaku usaha memperoleh pendapatan yang rendah, sisanya sebanyak $16 \%$ memperoleh pendapatan yang tinggi. Pelaku usaha mikro yang menyatakan tingkat pengembangan gerakan masuk dalam kategori tidak baik sebanyak $100 \%$ memperoleh pendapatan yang tinggi.

Hasil uji korelasi Rank Spearmanmenunjukkan koefisien korelasi sebesar $-0,325^{*}$ dan sig. (2-tailed) sebesar 0,028. Ini berarti tingkat pengembangan gerakan dengan tingkat pendapatan pelaku usaha mikro berhubungan negatif dan nyata karena nilai sig. (2-tailed) sebesar 0,028 < 0,05 (level of significant) dengan keeratan hubungan lemah. Semakin baik tingkat pengembangan gerakan maka semakin rendah tingkat pendapatan pelaku usaha mikro begitu pula sebaliknya.

Hubungan negatif ini disebabkan jumlah omset pelaku usaha mikro yang rendah. Rendahnya jumlah omset pelaku usaha mikro dipengaruhi oleh beberapa hal yaitu penggunaan dana pinjaman untuk keperluan pribadi yang tidak dapat mendatangkan keuntungan secara materil, seperti biaya sekolah anak dan juga tidak adanya pembukuan (administrasi) yang baik dan terinci mengenai berapa jumlah pemasukan dan berapa jumlah pengeluaran dari hasil usaha responden, sehingga tidak dapat diketahui secara pasti digunakan untuk apa saja uang tersebut.

\section{Hubungan Implementasi LKM dengan Tingkat Pendapatan Pelaku Usaha Mikro}

Lembaga keuangan formal di Indonesia dibentuk pada akhir abad ke-19 dengan dibentuknya Bank Perkreditan Rakyat (BPR) dan lumbung desa. Kedua lembaga ini dibentuk untuk mendampingi petani, pegawai, dan buruh untuk membebaskan mereka dari rentenir(Zeller etal., 1997). Banyak program pemerintah yang dianggap oleh berbagai pihak tidak mencapai hasil yang maksimal. Oleh karena itu, adanya LKM di dalam Posdaya diharapkan dapat membantu masyarakat untuk memperoleh akses terhadap modal, khususnya dalam pengembangan usaha.

Hasil uji korelasi Rank Spearman menghasilkan koefisien korelasi sebesar -0,183 dan sig. (2-tailed) sebesar 0,222. Ini menunjukkan bahwa implementasi LKM dengan tingkat pendapatan pelaku usaha mikro tidak berhubungan karena nilai sig. (2-tailed) sebesar 0,222 >0,05 (level of significant) dengan keeratan hubungan sangat lemah.

Semakin baik implementasi LKM tidak mempengaruhi terhadap peningkatan pendapatan pelaku usaha mikro. Ini disebabkan oleh beberapa faktor. Pertama, responden tidak menggunakan dana pinjaman untuk pengembangan usaha melainkan untuk keperluan pribadi. Kedua, tidak adanya pembukuan mengenai pemasukan dan pengeluaran rutin dari hasil usaha responden."Ketiadaan laporan keuangan pada UMKM umumnya dimulai pada keengganan mencatat setiap transaksi yang terjadi. Pencatatan transaksi merupakan kegiatan mencatat setiap transaksi yang berhubungan dengan kegiatan usaha. Sudah seharusnya semua transaksi yang berhubungan dengan kas, pembelian, penjualan, piutang, dan utang dicatat dengan tertib. Selain transaksi usaha, pelaku UMKM juga sudah seharusnya menginventarisir kekayaan/asetnya, baik aset lancar maupun aset tetap. Mencatat setiap transaksi sangat penting sebagai bahan untuk menyusun laporan keuangan." (Narsa et al., 


\section{Kesimpulan}

Implementasi LKM Posdaya Kenanga belum mampu meningkatkan pengembangan usaha mikro dari pelaku usaha mikro. Walaupun data menunjukkan bahwa implementasi LKM sudah baik. Ini dibuktikan dengan omset usaha dan aset usaha dari pelaku usaha mikro yang rendah serta terbukti dari hasil uji statistik bahwa masing-masing variabel dari implementasi LKM dengan pengembangan usaha mikro secara keseluruhan tidak berhubungan positif dan nyata.

Pengembangan usaha mikro yang rendah mempengaruhi tingkat pendapatan dari pelaku usaha mikro yang rendah, sehingga menyediakan akses masyarakat terhadap modal merupakan tindakan yang tepat. Rendahnya pengembangan usaha mikro dari pelaku usaha mikro dapat disebabkan oleh beberapa faktor berikut, seperti tidak adanya laporan keuangan, alat yang digunakan adalah alat-alat sederhana, dan dana pinjaman yang digunakan untuk keperluan pribadi.

ImplementasiLKMbelummampumeningkatkan pendapatan pelaku usaha mikro, sehingga menunjukkan program penyaluran kredit mikro oleh LKM Posdaya Kenanga belum berbasis pemberdayaan masyarakat. Ini dibuktikan dengan jumlah pendapatan pelaku usaha mikro yang sebagian besar rendah dan terbukti secara statistik tidak berhubungan positif dan nyata.

\section{DaftarPustaka}

Abdurrazzaq N. 2009. Evaluasi program Pos Pemberdayaan Keluarga (Posdaya) (studi kasus Posdaya Bina Sejahtera di Kelurahan Pasir Mulya, Kecamatan Bogor Barat, Kota Bogor, Jawa Barat). [skripsi]. Bogor (ID): Institut Pertanian Bogor. 107 hal.

Ashari. 2006. Potensi lembaga keuangan mikro (LKM) dalam pembangunan ekonomi pedesaan dan kebijakan pembangunannya. Analisis Kebijakan Pertanian. 04(02):146-164. [Internet]. [dapat diunduh dari: http://pse.litbang.deptan. go.id]

[BPS] Badan Pusat Statistik. 2006. Analisis profil perusahaan/usaha Indonesia. [Internet]. [dapat diunduh dari: http://daps.bps.go.id].

[BPS] Badan Pusat Statistik. 2012. Perkembangan beberapa indikator sosial-ekonomi Indonesia Agustus 2012. [Internet]. [dapat diunduh dari: http://www.bps.go.id].

[Depkop] Departemen Koperasi dan UMKM. 2011. Perkembangan data usaha mikro, kecil, dan menengah (UMKM) dan usaha besar (UB) Tahun 2009-2010. [Internet]. [dapat diunduh dari: http://www.depkop.go.id].

Hikmat H. 2004. Strategi pemberdayaan masyarakat. Bandung (ID): Humaniora Utama Press.

Khandker SR. 1998. Fighting poverty with microcredit: experience in Bangladesh. New York: Oxford University Press, Inc.

Krisnamurthi B. 2002. Strategi pembangunan ekonomi rakyat: dalam kerangka pembangunan ekonomi daerah. Bogor (ID): Pusat Studi Pembangunan IPB.

Kurniawan A. 2008. Faktor-faktor yang mempengaruhi produksi dan pendapatan usaha mikro dan kecil (studi kasus industri sepatu di Desa Sukaluyu, Kecamatan Tamansari, Kabupaten Bogor). [skripsi]. Bogor (ID): Institut Pertanian Bogor. 126 hal.

Marendra W. 2011. Kajian peran dan kinerja bank pemerintah terhadap pembiayaan sektor usaha mikro, kecil, dan menengah (UMKM) di Indonesia (perspektif kredit konsumsi sebagai kredit non UMKM. [tesis]. Bogor (ID): Institut Pertanian Bogor. 75 hal.

Muljono P, Dewi P, Bachtiar Y, Mintarti, Asikin S, Warcito, Haryanto S, Syafi'i H. 2010. Profil 50 Posdaya binaan IPB. Bogor (ID): P2SDM dan Damandiri.

Muljono P, Bachtiar Y, Mintarti, Dewi P. 2011. 101 cara mengenal Posdaya. Bogor (ID): IPB Press. Narsa IM, WidodoA, Kurnianto S.2012.Mengungkap kesiapan UMKM dalam implementasi standar akuntansi keuangan entitas tanpa akuntabilitas publik (PSAK-ETAP) untuk meningkatkan akses modal perbankan. Majalah Ekonomi. 22(03):204-214. [Internet]. [dapat diunduh dari: http://journal.lib.unair.ac.id].

Nuswantara B. 2012. Peranan kredit mikro dan kecil terhadap kinerja usaha kecil dan ekonomi wilayah di Provinsi Jawa Tengah. [disertasi]. Bogor (ID): Institut Pertanian Bogor. 248 hal.

[Pemkot] Pemerintah Kota Bogor. 2011. Monografi Kelurahan Kota Bogor. Bogor (ID): Pemkot Bogor 
Singarimbun M, Effendi S [editor]. 1989. Metode Penelitian Survai. Jakarta: LP3ES.

Triyanto A, Syamsun M, Saleh A. 2012. Bantuan dan kemitraan terhadap tingkat pendapatan UMK pengolahan hasil perikanan di Indonesia. Jurnal Manajemen IKM. [Internet]. [27 maret 2013]. 07(02):172-180. Dapat diunduh dari: http://journal.ipb.ac.id/index.php/jurnalmpi/.

Usman S, Soeharyo WI, Soelaksono B, Toyamah N, Mawardi SN, Akhmadi. 2004. Lessons learned from microfinance services in East Nusa Tenggara. Jakarta (ID): SMERU.

[RI] Republik Indonesia. 2008. Undang-Undang Republik Indonesia Nomor 20 Tahun 2008 Tentang Usaha Mikro, Kecil, dan Menengah. Jakarta (ID): RI.
Wijono WW. 2005. Pemberdayaan lembaga keuangan mikro sebagai salah satu pilar sistem keuangan nasional: upaya konkrit memutus mata rantai kemiskinan. Kajian Ekonomi dan Keuangan. Edisi khusus November 2005. [Internet]. [dapat diunduh dari: http://www. fiskal.depkeu.go.id].

Zeller M, Schrieder G, Von Braun J, Heidhues F. 1997. Rural finance for food security for the poor: implications for research and policy. Washington DC: International Food Policy Research Institute. 